\title{
Elite Interests and Public Expenditure in Education in the late XIX and early XX Century in Prussia: A Dialogue Between History and Economics*
}

\section{Intereses de élite y gasto público en educación a finales del siglo XIX y principios del XX en Prusia: un diálogo entre la historia y la economía}

Sebastián Enrique Acosta Madiedo Aranzalez BSc Economics Student, Facultad de Ciencias Económicas, Universidad Nacional de Colombia, Colombia https://orcid.org/0000-0001-7597-1168 seacostaa@unal.edu.co

${ }^{*}$ A preliminary version of this article is available at http://www.fce.unal.edu.co/media/ files/CentroEditorial/documentos/econografos/EE/econografos-EE-161.pdf

\section{ABSTRACT}

This paper discusses how Prussia's public education policy was intentionally guided by economic principles that modern economists have formalized and modeled. The essay compares the results of two economic 
models with the intentions held by Prussian government officials, which are enshrined in the research agenda of historians and academics. The paper concludes that Prussia's public education policy was intuitively and intentionally influenced by economic principles and intuitions of the theoretical and empirical models chosen.

Keywords: Prussia, education, expenditure, intentions, economic history.

JEL Codes: N33, N43, H30, H71, 120.

\section{RESUMEN}

Este artículo analiza la manera en que la política de educación pública de Prusia fue orientada intencionalmente hacia principios económicos que los economistas modernos han formalizado y replicado. El ensayo compara los resultados de dos modelos económicos con las intenciones de los funcionarios del gobierno prusiano, las cuales se encuentran recogidas en la agenda de investigación de historiadores y académicos. El documento concluye que la política de educación pública de Prusia fue intuitiva e intencionalmente influenciada por principios económicos y las orientaciones de los modelos teóricos y empíricos seleccionados para tal fin.

Palabras clave: Prusia, educación, gasto, intenciones, historia económica.

Códigos JEL: N33, N43, H30, H71, 120.

\section{INTRODUCTION}

Like most siblings, history and economics have a rocky albeit complementary relationship. They use vastly different tools to achieve the rigor required by the scientific method and often come to clashing conclusions. Nevertheless, there are times where historical research can enrich and nurture economic theory by showing that individual, governmental, and social class-based motivations and actions are consistent and commensurable with the mathematical and statistical models that tried to explain these very intents, spurs and decisions several years later. 
One case of brotherly cooperation between history and economics is the theoretical and empirical research surrounding the expansion of public education in Prussia between the last two decades of the 19th century and the first decade of the 20th.

When one looks closely at Galor and Moav's (2006) theoretical model, it is easy to find strong parallels between their theoretical development and the way in which Prussian officials planned and executed the country's educational policy 150 years ago. It is even possible to find in Friedrich Althoff a man who not only implemented taxation and investment in education as a means of economic growth, but also as an individual who saw the production of knowledge and human capital in Prussia as one would treat the production of consumer goods. On the other hand, Hollenbach's (2019) statistical findings are congruent with how historians portray the interests, aims and decisions of the Prussian industrialist elite and particular government officials throughout the 1880s, 1890 s and early 1900 s.

This paper will explore the connection between these two theoretical models and the intentions of two of Prussia's most prominent individuals, firstly, by giving a brief account of the public Prussian education in the late 1800 s and early 1900 s and its main objectives as a tool of economic and social policy and, secondly, by explaining Galor and Moav's (2006) model and Hollenbach's (2019) empirical findings. Finally, this work will also expose evidence of intentionality in Althoff's and Falk's decisions by reviewing the essays written by modern historians and economists, such as Lode Corneel Vereeck (1993), Peter Senn (1993), Hartwin Spenkuch et al. (2010a), ${ }^{1}$ and Jingyoung Yu (2011), a votum written by Minister of culture Adalbert Falk in 1877, and the University Bylaws of Prussian higher education institutions written in $1882 .^{2}$

The ultimate goal of this research is to make a small contribution to history and economics by fostering a dialogue between the two social sciences and showing how economic research can be enriched through historical sources. It will bring to light traces of modern economic intuitions, intentions and thought processes in historical institutions, social collectives, and individuals.

This essay was part of a compilation edited by Wolfgang Neugebauer in 2010.

Compiled by Paul Friedrich Dam. 


\section{THE PRUSSIAN EDUCATION SYSTEM AND ITS GOALS AT THE TURN OF THE CENTURY}

Prussia's education system is one of the oldest in the world. Started by Frederick the Great at the end of the 18th century, its scope, goals and purposes varied according with the time, place, context, and ruler. Nevertheless, education in Prussia always served the interests of the ruling class and the state, and was always seen as a tool to conduct government policy (Melton, 1988).

In the 19th century, Prussia started to see a pressing need toward industrialization, the production of more and higher-quality consumer goods, and decreasing its dependence on land. In order to do this, even before Althoff and Falk's time, some members of the Prussian government and its agencies started to tailor part of the education system, namely the Realschülen, toward economically driven interests and the qualification of the human capital for industrial labor (Büsch, 2012, p. 702).

In addition to the Kaiser and his advisor's realistic vision for Prussian future, the nobility was also changing its ways, albeit slowly and on an individual basis. Prussia's noble class was starting to see the potential benefits and profits of an industrialized society, as well as an opportunity to maintain its power and economic status. This drove many Prussian nobles to support the interests of industrialists and even to become industrialists themselves, which allowed them to remain in power and to continue to exert political influence in the country until 1914, amidst the rapidly declining relevance of agriculture in an increasingly industrialized Europe (Carsten, 1990).

The mixture of a historical event that was swaying Europe, and the fragmentation and individualization of a political class that remained united until the run of the century, brewed a fertile ground for the government to gradually change the course of its policies toward a welfare system of sorts that actively financed but also controlled public education economically, politically and in curriculum matters. It was under these conditions that Adalbert Falk and Friedrich Althoff could lead the country's education system with economic intuitions and intentions. 


\section{THE ECONOMIC ANALYSIS OF PUBLIC EXPENDITURE IN LATE 19TH AND EARLY 20TH CENTURY PRUSSIA}

Modern economists have tried to explain different historical contexts with the tools of their discipline since economics emerged. Educational policy in Prussia in the late 1800s and early 1900s is no exception.

This section will strive to outline the main ideas of the two most relevant models that have dealt with this topic: Galor and Moav's (2006) theoretical model, which outlines the conditions under which a society can transition toward a classless society through taxation, intergenerational transfers, and investment of public funds in education, as well as Hollenbach's (2019) statistical research, which found a causal relationship between levels of industrialization in Prussian cities and investment in education.

\section{Galor and Moav's Theoretical Model}

Galor and Moav argue that the demise of class society and the capitalist-worker dichotomy would only be possible through a cooperative effort between workers and industrialists, which would be reflected in a gradual increase in expenditure in public education (Galor \& Moav, 2006, p. 85). The dynamic and intertemporal allocation model proposed by these academics argues that it will be more profitable for the industrialist class to start investing in public education unilaterally through taxes than saving all of their profits for future consumption.

According to these authors, once enough physical capital is accumulated, investment in public education will improve the qualifications of the workers, making them more productive and increasing the profits of the next generation of industrialists. In addition, Galor and Moav also claim that this will increase the overall level of productivity, give more resources to the workers, and eventually encourage them to start contributing to the public education tax as well.

This investment will gradually converge to a steady state equilibrium, where wealth and resources will be distributed optimally and equally across all members of society. The authors also call the steady state equilibrium the point of class society's demise (Galor \& Moav, 2006, p. 103). 


\section{The Short and Unwinding Road to a Classless Society: A Graphic Approach}

The model (figure 1), just like the Gregorian calendar, is divided into two eras: before and after the birth of public education. The era before public education goes from $y_{0}$ to $\hat{y}$. The authors assume that public education exists at every point after $\hat{y}$. The second era or regime, as the authors call it, is also divided into two stages. The first goes from $\hat{y}$ to $\hat{y}$, and models the time between the birth of public education and the time in which all people, regardless of social class, start to contribute to the tax system. The second stage lies between $\hat{y}$ and $\hat{y}$, and shows the transition from a society where everyone can contribute to the tax system to one where social classes no longer exist.

The variable on the vertical axis is measured in overall future productivity per worker units $y_{t+1}$. It depends on the current productivity level per worker $y_{t}{ }^{3}$ The current labor productivity per worker, in turn, is a function of both the current tax rate $\tau_{t}$ and aggregate intergenerational transfers $\mathrm{B}_{\mathrm{t}}\left(\mathrm{b}_{\mathrm{t}}^{\mathrm{R}}, \mathrm{b}_{\mathrm{t}}^{\mathrm{P}}\right)$. Each lower case $b_{t}$ represents the intergenerational transfers from the wealthy capitalist class $R$ and the poor working-class $P$.

Figure 1. The three stages to reach a classless society

Source: Simplified version of the figure found in Galor and Moav (2006, p. 105).

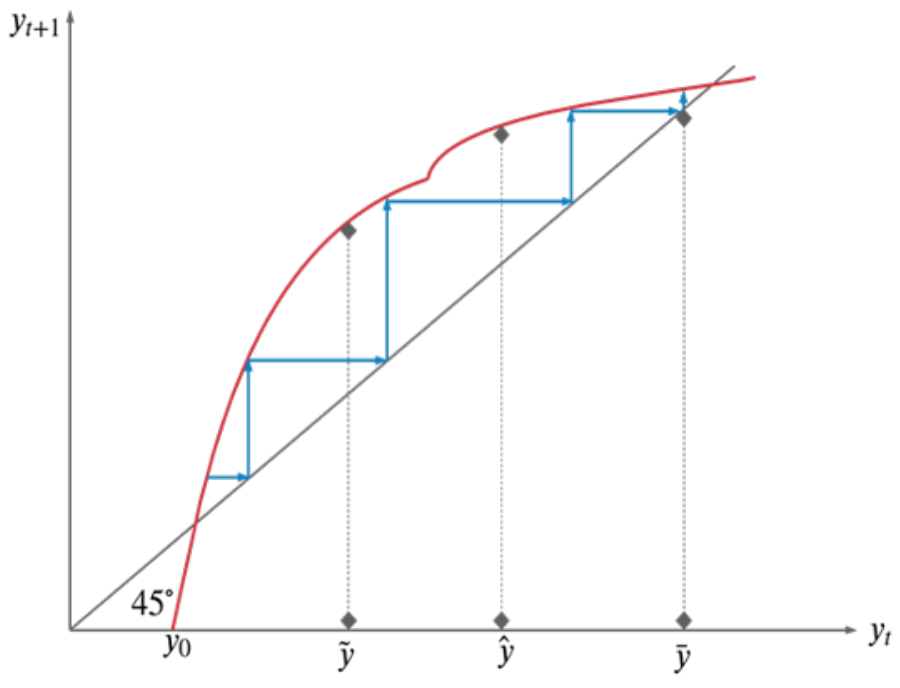

The evolution of output per worker behaves differently in each regime and stage. In regime 1, the output is given by:

$$
y_{t+1}=\operatorname{Max}\left\{A\left[\beta\left\{[\lambda(1-\alpha)+\alpha] y_{t}\left(\tau_{t}, B_{t}\right)-\lambda \theta\right\}^{\alpha}\right], 0\right\}[1]
$$

This means that regime change will depend on current levels of productivity. Once a certain level of productivity is reached, society will transition to the next stage. 
The other variables represent technological development $A$, the minimum wage necessary to make intergenerational transfers possible $\theta$, the share of capital in total output owned by the capitalist class $\alpha$, and the weight or importance that people give to intergenerational transfers $\beta$.

In regime 2, stage I, the evolution of output per worker behaves according to the following expression:

$$
y_{t+1}=A\left[\left(1-\tau_{t}\right) \lambda b_{t}^{R}\right]^{\alpha}\left[h\left(\tau_{t} \lambda b_{t}^{R}\right)\right]^{1-\alpha}[2]
$$

The only new variable $(\alpha-1)$ represents the share of capital in total output not owned by the wealthy capitalist class. This stage is the first where investment in physical capital by the working class is possible. This characteristic is shown by the curve's kink in the middle of the interval between $\hat{y}$ and $\bar{y}$ in figure 1 .

In stage II of regime 2, this evolution will be shown by the expression:

$$
y_{t+1}=A\left[\left(1-\tau_{t}\right) \beta\left[y_{t}-\theta\right]\right]^{\alpha}\left[h\left(\tau_{t} \beta\left[y_{t}-\theta\right]\right)\right]^{1-\alpha}[3]
$$

This stage of the model is the first one where the working class is willing and able to contribute to the public school system through taxes. In other words, this is the stage at where the previous investments, made by the rich capitalist class, are having an effect on the working class and are generating social mobility. It is also the first stage where the proletariat performs intergenerational transfers. Before this point, the model assumes they do not have enough capital; thus, no economic capability to do so.

It is also important to note that, at this stage, the curve in the graph becomes smoother because of a greater propensity to save, coupled with a larger and better income. This behavior means people will consume less in the present, lower the tax rate, and transfer the money directly to the next generation for future consumption. This feature of the model can be considered a prelude to the moment in which society reaches the steady-state equilibrium, a point at which productivity, technological advancement, tax rates, wages, the rate of direct intergenerational transfer, and capital distribution are equal and constant.

Galor and Moav's equations and graph show that society's road to classlessness will depend on cooperation between the rich capitalist class, which owns the means of production, and the working class, which starts off with nothing but progressively gets richer due to the intergenerational 
transfers performed by the rich property owning capitalists in the first two stages of the model.

The economic principle behind this dynamics lies in the fact that an increase in income will improve the overall quality of human capital, which will, in turn, improve labor productivity. ${ }^{4}$ In short, the model argues that cooperation between different social classes rather than violence and class struggle are the keys to achieving a classless society. ${ }^{5}$ Hence, the authors built a model where the productivity of the workforce increases with proper wages and time, better technology, and better education, and where education improves through the willingness of the ruling elites to pay their taxes.

\section{Hollenbach's Empirical Model}

Taking Galor and Moav's Model as his inspiration (Hollenbach, 2019, p. 3), Hollenbach employed the model that the original researchers applied in the United Kingdom and used it to analyze public expenditure in education and its relationship with industrialization in Prussian cities in the 19th century. ${ }^{6}$ The result was a causal relationship between per capita public expenditure in education and industrial employment: the variable he used as a proxy for industrial elite capital ownership (Hollenbach, 2019, p. 1).

The author used three statistical models and the data from Prussian cities collected on the German census of 1907 to reach his goal. First, he performed six simple ordinary least squares (OLS) regressions to find a correlation between per capita expenditure in education and the level of industrialization in Prussian cities. Afterward, he performed a generalized spatial two-stage least square model (GS2SLS) to account for and mitigate the effects of spatial spillovers and spatial dependence between some variables in the models. Finally, he used an instrumental variable model to reaffirm his findings and prove a causal relationship between his two variables.

This economic principle, namely that economic growth and labor productivity are tied to the quality of human capital, was first described by Robert Solow and Trevor Swan in 1956. Nowadays, this model is considered part of the undergraduate (and sometimes the fundamental component of a graduate program) canon in macroeconomics in many universities around the world.

5 The thesis of the model goes, explicitly, against Marx's argument. The German economist and philosopher argued that the ruling capitalist elite had to be eliminated and that a dictatorship of the proletariat should be put in its place in order to transition to a classless society. In contrast, Galor and Moav argued that a classless society would only be achieved through cooperation.

6 Hollenbach collected the data of 110 cities from different sources. Nevertheless, he used the 1907 census performed by Prussian authorities as his blueprint. For a more thorough review of the data and the sources it was taken from, see the electronic supplement to Hollenbach (2019), found for free at https://link.springer.com/article/10.1007/s11558-019-09347-z\#Sec10 


\section{The Simple OLS Regression Model}

Hollenbach began his research by performing a set of simple OLS regression models. Instead of taking a particular parameter as his reference frame, he decided, first, to perform three separate tests with different amount of control variables: applying no control to his first test, a limited number of controls for his second test, and a full array of controls, which included province fixed effects, the difference between population parameters and the full hypothesis, in the third test. The general formula used for these regressions was:

$$
y_{i}=\alpha+\beta_{k} X_{i, k}+\gamma \text { industrial }_{i}+\varepsilon_{i}, i=1, \ldots n .[4]
$$

where $y_{i}$ is the measure of educational investment in a particular Prussian city, according to German the census of 1907; $\alpha$ is the common intersect; $X_{i, k}$ is the matrix of control variables; $\beta_{k}$ the corresponding vector of coefficients; industrial the variable that measures industrial employment in city $i$. Finally, $\gamma$ corresponds to the estimated rate of change in education expenditure when a marginal change in industrial employment occurs and $\varepsilon_{i}$ is the error term.

The main result drawn from these regressions was that expenditure in education was highly sensitive to industrial employment, since one standard deviation increase from the mean in the independent variable was related to a $6 \%$ increase in per capita public expenditure in education. ${ }^{7}$ Furthermore, the author also claims that all his tests were statistically significant at a level of $5 \% .{ }^{8}$ Hollenbach also noted that his confidence interval did not include the number 0 , which means that, no matter how slight, there would always be an impact of per capita investment in education over industrial employment (Hollenbach, 2019, p. 15).

The author confirmed his findings by correlating industrial employment and education enrolment. The results obtained when changing the dependent variable —while leaving the proxy for industrialization and the three mechanisms of control intact - yielded similar results to those he obtained when regressing public education investment (Hollenbach, 2019, p. 15).

This means that for every new or additional industrial job in one of the 110 Prussian cities taken into account by this model, per capita educational expenditure from the government increased in $6 \%$ in this particular city.

8 This means that the probability of committing a type-1 error or rejecting the null hypothesis when it is assumed to be true is $5 \%$. 


\section{The Spatial Autoregressive Model}

Despite its robustness, Hollenbach was not satisfied with the results obtained by the first set of linear regressions because they did not account for potential spatial spillovers and correlations between cities that were close to one another.

The author argued that, although not every city and town was an industrial center, smaller cities near an industrial center could also see an increase in demand for public education. Also, local elites from nearby urban centers with less industrial capabilities could become free riders of industrial centers elites. These situations could have an impact on the original regressions and even generate biased estimates (Hollenbach, 2019, p. 15). His suspicions were confirmed by a Moran's I test, through which the academic was unable to reject the null hypothesis of no spatial correlation in the residuals (Hollenbach, 2019, p. 15).

To account for this, the author decided to build a GS2SLS model that included the spatial lag for the dependent variable by adding the industrial employment in every other city $y_{j}$ and the neighboring structure of $y_{i}$ (embodied in $w_{i, j}$ ) to the original model. When placed together, these variables created a weighted average of adjacent cities' influence on the dependent variable (Hollenbach, 2019, p. 16). The author's proposed equation for this new model was:

$$
\mathrm{y}_{\mathrm{i}}=\lambda \sum_{\mathrm{j} \neq \mathrm{k}} \mathrm{w}_{\mathrm{i}, \mathrm{j}} \mathrm{y}_{\mathrm{j}}+\alpha+\beta_{\mathrm{k}} \mathrm{X}_{\mathrm{i}, \mathrm{k}}+\gamma \text { industrial }_{\mathrm{i}}+\varepsilon_{\mathrm{i}}[5]
$$

All the variables assigned with a meaning in the original model do not change in this one. $\sum_{j \neq k} w_{i, j} y_{j}$ accounts for the weighted average of the spatial lag generated by every other city included in the model, while $\lambda$ accounts for the spatial correlation parameter. The new variable values were based on the inverse distance between cities, which later were row standardized (Hollenbach, 2019, p. 16). ${ }^{9}$

The researcher found that the final results obtained from the GS2SLS were similar to those of the original OLS regression and that -although there was a possible spatial dependence - the spatial correlation parameter decreased substantially when province fixed effects were taken into

9 For a comprehensive explanation of the logic behind the model used by Hollenbach, see Maximum likelihood and generalized spatial two stage least squares estimators for a spatial autoregressive model with spatial autoregressive disturbances, by Drukker et al. (2013). 
account (Hollenbach, 2019, p. 16). In other words, the results indicate that the distance from the cities to industrial zones located in other urban centers had little to no impact on educational expenditure, and thus, that using industrial employment as the dependent variable and as a proxy to measure industrialization in the original model in each individual city made sense, since this variable would only measure how industrialized each individual city (or observation) was, not being affected by the employment supply of other neighboring cities.

After obtaining these results, Hollenbach's research faced only three threats: the lack of strength in his findings - which until now proved no causal link between the proxy for industrialization and education-, omitted variable bias - which meant the results could be altered if some variables in the error term where made explicit in the regression models-, and reverse causality — which implied that an increase in public education expenditure caused a greater degree of industrialization and not the opposite (Hollenbach, 2019, p. 16).

To counter these issues, the author decided to treat industrial employment as an endogenous variable and use a geographic exogenous instrument for the model: the location of carboniferous rock strata. He used this measurement as his instrumental variable because another paper had pointed out that carboniferous areas were highly correlated with later coal discoveries, and coal was one of the most critical natural resources required to power factories in the industrial era (Hollenbach, 2019, p. 17). ${ }^{10}$ The result, as expected, was a robust negative correlation within the bivariate regression between logged distance to carboniferous strata and industrial employment, yielding a $R^{2}$ equal to 0.42 (Hollenbach, 2019, p. 17). ${ }^{11}$

Although Hollenbach is aware that he cannot prove that the covariance between the instrument and the unobserved error is a necessary assumption for performing the instrumental variable regression, he appeals

10 To obtain more information about the relationship between coal and carboniferous strata, see Coal and the European industrial revolution. University of Oxford: Discussion Papers in Economic and Social History, by Fernihough \& O'Rourke (2014).

11 According to the author, the robust $F$ statistic for the first stage of the test with a full set of controls was 16.41 and 17.64 in the one with partial controls. Compared to the available evidence, according to the author, these numbers show that the instrument is considerably strong to predict industrial employment (Hollenbach, 2019, p. 17). Although the author does not mention it directly in the paper, his statement seems to imply that Hollenbach is referring to a high degree of dispersion between the distances of different cities and carboniferous areas from the mean distance and that this significant dispersion makes the instrumental variable effective. 
to the reader's common sense. Then, he argues it is highly unlikely that carboniferous strata influence the political process or the decisions of Prussian politicians; not least because rock strata precede political deliberation by a few million years (Hollenbach, 2019, p. 17).

The academic also counters the concerns on "the influence of spatial dependence because of the geographic nature of the instrument" (Hollenbach, 2019, p. 18) by performing another spatial two-stage least square model that uses the same variables as the original GS2SLS. Once again, the results of the Spatial 2sls model with heteroscedastic standard errors yielded similar results to those found in the original OLS model and the GS2SLS model (Hollenbach, 2019, p. 18-19).

The spatial-2sls results, according to Hollenbach, suggest a causal effect of industrial employment on education expenditure in a similar way in which OLS suggested a correlation between these variables. The research's general conclusion is that the members of an elite group will only invest in education if their investment increases the elite's return on capital (Hollenbach, 2019, p. 19).

Now that economics has provided a solid theoretical frame and a wealth of empirical evidence that shows a causal link between government spending in education and industrialization, we can proceed to prove that these findings were not incidental. Besides, the existence of a convincing amount of evidence shows that the intentions of historical actors, entrepreneurs and the German government had a significant economic grounding.

\section{THE ROOTS OF ECONOMIC INTENTIONS IN GERMANY'S EDUCATION POLICY}

To trace the economic intentions of Prussian government policy education we only have to turn back the clock to the early 1870 s. Although the policy enacted throughout this decade was not as significant as later decisions, it shows that a faction of government officials, industrialists and politicians were thinking about educational policy through the lens of economics. 


\section{The First Attempt at an Educational Reform Grounded on Economics: The Sorrows of Minister Falk}

The most prominent but forgotten attempt to reform education in Prussia in favor of the industrialist elite's economic interests and concerns was led by the Education, Religion and Medical Affairs Minister of the time, Adalbert Falk.

Falk is generally remembered by current historians as the minister of the culture wars and is portrayed as a politically motivated man. His educational reform of 1872 is described as a political maneuver to eliminate the influence of the catholic church from public education, at best, and as a measure to place Prussia at the forefront of competition between German states at worst. ${ }^{12}$ Even so, his government votum, ${ }^{13}$ sent to the ministry of the state on June the 7 th, 1877, shows a different perspective.

Even though the first section of the votum shows a politically committed and ideologically charged minister, in the second section Falk expresses concern over "the current measures for the maintenance of public schools," which had "become completely unsustainable." According to the minister, "new unbearable burdens are ladening the state treasuries, and the rural communities are being unable to provide (public education) as they are supposed to" (Neugebauer, 2010b, p. 247).

The minister's supported his claims by referring to the multiple discussions that the Landtag and the Herrenhaus had over this topic and a legal quarrel between a Prussian conservative politician and the local Lutheran church in Pleß. The proposal of the minister was to "further increase the support of the Prussian central government (for public education); support increase which, although hotly debated in parliament and government, seemed to yield unjust results" (Neugebauer, 2010b, p. 247).

Despite his arguments and pleas, Spenkuh's and Paetau's essay claims that minister Falk's proposal would end up being abandoned after the finance ministry considered the proposal too expensive and unnecessary to implement. Falk's project was too ambitious, for it proposed to reform all areas of education. It was expensive because it would have meant investing

12 Education in Germany in the 19th century was regulated autonomously by each German state. Falk, as a minister for the Prussian government, only had influence in Prussia.

13 Government Vota - a Latinism that is generally translated as vows in English — was the name given to certain government documents in Prussia and Germany throughout the 19th century, which outlined and communicated the plans and commitments of a Minister and his institution to the rest of the government and the emperor. 
two-fifths of Falk's ministry's total budget in the reform. It was inconvenient since the Kaiser and Bismarck had shifted their policy towards the culture war in the late 1870s, and therefore secularizing education was no longer a priority for them (Neugebauer, 2010a, p. 62)..$^{14}$

Regardless of his failure, Falk's small but significant contribution to the education system embodied in the educational reform of $1872,{ }^{15}$ in addition to what he expressed through his votum, shows that this individual, at one of the highest government levels, had the intention of enacting reforms on the schooling system based, at least partly, in economic intuitions and the economic interests of the industrialist elite, which in turn was advocating for a more public and state-controlled education; a proposal that would make this service more accessible, but subordinate to the interests of the state and the industrialists. This, in a nutshell, is commensurable and very similar to the proposal of Galor and Moav.

\section{The Intentionality of private in Public Interests: German entrepreneurs financing education for the public}

Although Falk's attempts at a radical education reform failed, he was not the only individual striving to change Prussia's education. The industrialist class was also actively trying to make the school system serve their interests by financing and promoting, privately, the creation of trade schools and technical institutions. It is important to note that, in contrast to Falk, who also had political motivations to advocate for it, the leaders of the German industry were solely concerned with increasing their profits.

The intentions of private industrialists, and the zeal with which they defended their private interests by sponsoring education, are better illustrated by Dr. Jingyoung Yu. In her Ph.D. thesis, Dr. Yu brought evidence from statistics of that period which showed there were 213 trade schools with 21,000 students in Prussia alone. To reaffirm the independent and private character of this endeavor, Dr. Yu quotes the director of trade schools in Kiel,

14 The culture war was a political struggle between the German government and the catholic and Lutheran churches. The struggle permeated the political, social and economic spheres. Falk was very close to the National Liberals, who were committed to secularize education on both ideological and economic grounds. His reform proved too progressive for the Kaiser at that time and was one of the main reasons for the emperor to dismiss him in 1979.

15 The Kaiser enacted an education reform in 1872 that separated the mittelschule (or middle school) from the elementary school, and placed all elementary, middle and high schools under state control, taking it away from the Church. The legislation proposed in the votum would expand the state's powers at the school level, regulate universities, and surrogate all education in Prussia to the interests of the state. 
who claimed that, during the 1870s, Falk's ministry had left the task of sponsoring, organizing and managing trade schools to industrialists with private interests and ordinary citizens (Yu, 2011, p. 36).

Through Helmut Naunin's work, Dr. Yu also argues that the bourgeoisie of that time got increasingly aware of its responsibility to the community. This fact increased the bourgeoisie's prestige and consolidated position of power, which was ultimately grounded on economic stability and not political connectivity or proximity to the central government (Yu, 2011, p. 38).

The main argument one can derive from the author's analysis is that the intentions of the industrialists - a more productive labor force- was not only a pipe dream that sometimes was championed by the central government, but rather an active, constant and self-regulated effort of industrialists, who left the evidence of their intentions in their independent investment on the Prussian education system through trade schools.

These intentions are aligned to the economic models exposed. Only the regions with a strong presence of industrial class would autonomously create these kinds of trade schools, which would be similar to Hollenbach's proposal of localized government expenditure based on the degree of industrialization, and only the children of working-class members of society would attend these trade schools. Also, they were specifically designed for vocational training, and most members of the Bourgeois wanted more than mere vocational training for their offspring, which is similar to the proposal of Galor and Moav.

\section{THE DAWN OF THE ALTHOFF SYSTEM}

Due to the liberal climate of self-regulation and the increase of privately sponsored higher education institutions, minister Puttkamer, the conservative who followed Falk, was ousted from the Ministry of Culture, Education and Medical Affairs. Gustav Konrad Heinrich von Goßler was put in his place, and Friedrich Althoff - a simple government official until that time- started to implement the set of policies that would revolutionize the Prussian education system through economic thought. Although minister von Goßler's administration was not particularly conservative, his tenure would have probably gone unnoticed in education had it not been for Friedrich Althoff. 
Althoff was not a career politician, nor an idealist and, most definitely, not a conventional bureaucrat. He earned prominence because of Goßler's tenure and remained prominent after Goßler was dismissed, not only for actively defending the industrialists' interests at the state level but also for managing universities as firms, knowledge as a national resource, and education as an instrument of economic policy. This man started to gain prominence in 1882, when he received a call from the ministry to become a referendar, ${ }^{16}$ whose task was to appoint academic personnel. Although his official post had a pretty limited scope, those same years he was already performing significant contributions in matters of scientific and educational policy (Vereeck, 1993, p. 30).

The reason for Althoff to be able to accumulate so much power and exert so much influence through so many functions was partly due to the role of Prussian bureaucracy and partly due to his personal style. On the one hand, Prussia had a bureaucracy that was tasked, first and foremost with the welfare, stability and progress of the country and its citizens, in stark contrast to other monarchies, where bureaucracy was used to project the power of the king. On the other hand, Althoff's personality was suited to the accumulation of work and power. The man was prone to micromanagement and thrived under stress (Peirce \& Krüger 1993, p. 62-64).

The cornerstone of Althoff's system was to see research and education as a public good with externalities. He was the first one to consider knowledge as nonexcludable and nonrival, and to consider that its production generated effects on third parties which had positive and negative consequences to firms, industries and individuals (Vereeck, 1993, p. 17). This vision is also supported by Wolfgang Neugebauer, who, in his chapter published on a collection of essays on Prussian history, argues that the Althoff system was a great entrepreneurial endeavor controlled and managed by the state, which had a particular vision of the future, namely the economic welfare of Germany, and a network of hand-picked highly qualified employees, whose function was not only to improve the human capital available to work in firms and perform academic researches but also to use this specialized human capital to research specific fields that where of interest to the state and to the betterment of its economy (Büsch, 2012, p. 766).

16 Term used in Germany to refer to civil servants in training, who would later get senior positions in a public institution. 
Althoff was so committed to the quality of his product - namely academic research, scientific progress and mass production of highly qualified human capital - that he decided to make tenured professors some of the best paid employees in Germany, giving them economic incentives, handpicking them personally, as if he was the CEO of a modern corporation, and fostering and environment of brutal competition between applicants and amongst the faculty to ensure only the best of the best would continue to hold their jobs for extended periods of time (Senn, 1993).

When called by the ministry to become an advisor, this man designed a system based on six principles connected through his cornerstone idea of education as a public good and universities as a fiercely competitive firm, which guided the Prussian education system until 1910. These principles were the bureaucratization and professionalization of the university administration, tighter government control on the system of employment for professors, the specialization of universities in particular areas of knowledge, the procurement of private funds for research, the creation of fruitful academic relationships with universities abroad, and the creation of a network of foreign contacts within universities that would help the government to attain these goals (Neugebauer, 2010a, p. 172).

Out of these principles, four had a direct economic intuition lying behind them. The first aimed to increase the university's labor productivity, making it a more efficient producer of professionals who would enter the labor market and knowledge or research which would be useful for the state. The second principle would contribute to the same goal: university professorship would become like any other job, a careful selection process from which the most capable and productive worker can emerge. The third one, probably the most congruent with Hollenbach's research, had to do with regional specialization. This specialization was made to meet the needs and interests of those who funded the research, mostly were private industrialists.

Finally, the fourth principle shows economic intentionality because it aligned the interest of public universities with the interests of those who were willing and able to fund a research and were interested in doing so. The transactional character of this measure and the intention behind the initiative was so clear, that Althoff established the Kaiser Wilhelm Institut and funded scholarships through this institution; even Siemens took advantage of Althoff's scholarship programme (Neugebauer, 2010a, p. 198). Thus, the 
university became a direct service provider for industrialists, who would help finance and sponsor this body in exchange for its targeted research.

The principles for which Althoff advocated intuitively implemented the most important ideas from the model of Galor and Moav into government policy, by doing so, these very same principles paved the way to validate Hollenbach's empirical research.

It is important to highlight that some parts of the policy were designed for the industrialist class to invest directly, independently and privately instead of relying on taxes, a key feature of Galor and Moa's model. Even so, the Althoff system was set up to produce what Galor and Moav's model theory wanted to produce, that is, high-quality specialized research (technology) and a professionally and technically capable human capital. In other words, research and people who served the interests of the industrialist elites and the state. This government policy was so successful that its consequences soon became an integral part of the bylaws of several Prussian and German universities in general.

\section{INTENTIONS ENGRAVED IN STONE: THE UNIVERSITY BYLAWS AFTER ALTHOFF}

The legacy of Friedrich Althoff did not limit itself to increasing the prestige of Prussian universities abroad. The policies eventually reached the documents of government and the statutes of the universities he set himself to reform in 1882. The evidence of his work was collected by Paul Friedrich Damm, who compiled the bylaws of several universities around the German empire. According to the editor's sources, the University of Berlin stated mission was to "provide the best education for the industrial life of the state and the municipality" (Damm, 2019, p. 55).

The bylaws also state that the institution was "entirely subordinated to the ministry for cultural, educational and medical affairs" (Damm, 2019, p. 55). The ministry had the power to determine and increase or decrease "the departments of the university and their respective disciplines" (p. 55). He also had to appoint a government official who would supervise "all economic questions of the university, and support the headmaster for taking all the material related decisions of the university" (Damm, 2019, p. 66). These two provisions gave all effective control of the academic direction and the 
university's economic expenditures to the government. This document was approved in 1882, and it remained unchanged until the end of the First World War. It was Althoff's first act as a prominent government official, and it would outlast his reign in power.

Beyond the impact of Althoff and his legacy, these documents show that, by the early 1880 s and throughout the following three decades, the government would intentionally adopt a capitalist interest-driven policy; one in which industry and productivity, sponsored by government and private funds, were at the forefront of the decisions of the government. The Althoff system also shows that at the beginning of the decade it was not only industrialists and individuals but also the government who was also intending to drive its educational policy along economic lines.

In addition, the policies outlined by the bylaws are also entirely consistent with the model of Galor and Moav since they subordinate the administration of education to the state and provide public funding while at the same time make education a tool for the industry. Furthermore, these bylaws are also consistent with Hollenbach's findings: the university could adapt its curriculum according to the industrial needs of a city. As its finance depended entirely on a government official, this official could deem the university useful or useless in the function of the industry it served.

\section{CONCLUSIONS}

Throughout this paper, individuals' historical intentions, a social class and a government were analyzed in order to trace clusters of economic thought based on two models. After a thorough analysis, the main conclusion overwhelmingly shows that the economic intuitions of the models by Hollenbach, Galor and Moav were present in Prussian policymakers, industrialists and government, remaining in force since the 1880s until the start of the great war.

A secondary conclusion is that Galor and Moav's theoretical model and Hollenbach's empirical model are consistent with the economic reality of Prussia and their results are not the product of chance nor coincidence. Those results reflect concrete economic intentions and actions of historical actors at a particular time. 
These two conclusions fulfil the paper's aims, namely, to foster a dialogue between history and economics and to enrich economic theory through history, by showing how primary and secondary sources can give names, lives and intentions to stakeholders and prominent figures that economics treats as simple variables.

Further studies should find similar correlations in areas such as healthcare expenditure or expenditure in other industrial goods. On the historical side, a deeper investigation of the available primary sources, on the ministry of finance documents, and this ministry's attitude throughout Althoff's administration would also enrich the field. Further questions can also be asked about the attitude, intentions, and decisions of other historical actors, such as conservative rural elites, whose perspective was left out of this analysis.

The impact of particular historical events, paramount to the history of Prussia and Germany, should also be analyzed more deeply in future research. This is a fertile and unexplored field with many areas that can be discussed in other papers with either a broader or a different scope.

\section{REFERENCES}

Büsch, O. (2012). Das 19. Jahrhundert und Große Themen der Geschichte Preußens. De Gruyter. https://doi.org/10.1515/9783110839579

Carsten, F. (1990). Der preußische Adel und seine Stellung in Staat und Gesellschaft bis 1945. Geschichte Und Gesellschaft. Sonderheft, 13, 112-125. http://www.jstor.org/stable/40194825

Damm, P. F. (2019). Die Technischen Hochschulen in Preussen: Eine Darstellung Ihrer Geschichte Und Organisation; Nach Amtlichen Quellen. Forgotten Books. https://books.google.com.co/ books?id=-tRStAEACAAJ

Drukker, D. M., Prucha, I. R., \& Raciborski, R. (2013). Maximum likelihood and generalized spatial two-stage least-squares estimators for a spatial-autoregressive model with spatial-autoregressive disturbances. The Stata Journal, 13(2), 221-241. https://doi. org/10.1177/1536867X1301300201 
Galor, O., \& Moav, O. (2006). Das Human-Kapital: A theory of the demise of the class structure. The Review of Economic Studies, 73(1), 85-117. https://doi.org/10.1111/j.1467-937X.2006.00370.x

Hollenbach, F. M. (2019). Elite interests and public spending: Evidence from Prussian cities. The Review of International Organizations, 16, 189-211. https://doi.org/10.1007/s11558-019-09347-z

Melton, J. V. H. (1988). Absolutism and the eighteenth-century origins of compulsory schooling in Prussia and Austria / James Van Horn Melton. Cambridge University Press.

Neugebauer, W. (2010a). Acta Borussica: Neue Folge, 2. Reihe: Preußen als Kulturstaat, Abteilung I: Das Preußische Kultusministerium als Staatsbehörde und gesellschaftliche Agentur (1817-1934), Band 2.1: Das Kultusministerium auf seinen Wirkungsfeldern Schule, Wissenschaft, Kirchen, Künste und Medizinalwesen: Darstellung. Akademie-Verlag. https://nbn-resolving.org/urn:nbn:de:kobv:b4-opus-25315

Neugebauer, W. (2010b). Acta Borussica: Neue Folge, 2. Reihe: Preußen als Kulturstaat, Abteilung I: Das Preußische Kultusministerium als Staatsbehörde und gesellschaftliche Agentur (1817-1934), Band 2.2: Das Kultusministerium auf seinen Wirkungsfeldern Schule, Wissenschaft, Kirchen, Künste und Medizinalwesen: Dokumente. Akademie-Verlag. https://nbn-resolving.org/urn:nbn:de:kobv:b4-opus-25323

Peirce, W. S., \& Kruger, P. (1993). Entrepreneurship in a bureaucracy: The case of Friedrich Althoff. Journal of Economic Studies, 20(4/5). https:// doi.org/10.1108/EUM0000000000171

Senn, P. R. (1993). Where is Althoff? Looking for Friedrich Althoff in English language sources. Journal of Economic Studies, 20(4/5). https://doi. org/10.1108/EUM0000000000179

Vereeck, L. (1993). The economics of science and scholarship: An analysis of the Althoff System. Maastricht University Datawyse/Universitaire Pers Maastricht.

Yu, J. (2011). Die Entwicklung berufsbildender Schulen in Preußen, Sachsen und Württemberg zwischen 1869 und 1914 (Doctoral dissertation, Leibniz Universität Hannover). Leibniz Universität Hannover Repository. https://www.repo.uni-hannover.de/ handle/123456789/7845 